\title{
Impulse Buying: The Effect of Price Fairness, in Store Promotion, Merchandise and Time Availability
}

\section{H Haryanto, W Wiyono, and Dwi Hastjarja KB}

Management Dept of Faculty of Economic and Business, Universitas Sebelas Maret, Indonesia

\section{Abstract}

Impulse buying is unplanned purchases but have a significant impact on retail sales. This study examines the effect of price fairness, in store promotion and merchandise on impulse buying behavior. Research respondents were taken purposively with the criteria of members of the population who had made impulse buying. The population of this study is citizen of Surakarta who became consumers of the national mini retail chain. Data collection using questionnaires that have passed the validity and reliability test, while data analysis uses PLS SEM. The result of the study shows that Price Fairness, In Store Promotion, and Merchandise variables influence impulse buying

Corresponding Author: H Haryanto ayahromo@gmail.com haryanto@staff.uns.ac.id

Received: 10 February 2019 Accepted: 14 March 2019 Published: 28 March 2019

Publishing services provided by Knowledge E

(c) H Haryanto et al. This article is distributed under the terms of the Creative Commons

Attribution License, which permits unrestricted use and redistribution provided that the original author and source are credited.

Selection and Peer-review under the responsibility of the ICIEBP Conference Committee. behavior, with a T statistic score of 2,047; 2,537; and 2,104 respectively. The score is above the cut-off required for the $5 \%$ significance level, which is a statistical $T$ value of more than or equal to 1.96 . Furthermore, the time availability variable is not a moderating variable.

Keywords: Impulse Buying, Price Fairness, In Store Promotion, Merchandise, Time Availability, Retail

\section{Introduction}

Impulse buying is retail consumer behavior that is not based on planning when making transactions. This type of purchase usually occurs spontaneously which is influenced by the external situation of the consumer towards the consumer's emotions. Therefore, Park (2006) stated that a marketer must pay attention to the positive emotional state of a consumer while in the store. Positive emotions are emotions that can cause a sense of well-being in someone. The emotional state of a consumer can be influenced by a store atmosphere which will influence purchases (Rusdian, 1999).

The store atmosphere that can influence consumers in making purchasing decisions consists of various variables, including the fairness of prices. Fairness of price is the assessment of consumers against nominal prices compared to what is obtained. In addition to price fairness, the variable in store promotion also has an influence on the 
formation of consumer shopping behavior. In store promotion is all forms of promotion carried out by retailers in the store.

In addition, impulse buying also depend on the internal factor of consumers, in this case is the availability of time for consumers to shop. Consumers who have relatively much time when shopping, their behavior is different from consumers who have limited time when shopping.

Most studies on the effect of moderating time availability are carried out at large retail (Balaji \& Babu, 2015; T. Chen, 2008;Tinne, 2010), studies on mini markets are still rarely carried out. Therefore, research of impulse buying in mini market settings is interesting to do.

\section{Literature Review}

\subsection{Price fairness}

Zeithaml (1988) stated that price is a consumer sacrifice to get the benefits of a product. Based on that definition, price is a consumer's perception which refers to consumer valuation based on both the information received and the experience got. Therefore, the perception of prices leads to the appropriate price conditions, not about lower or higher prices.

The price perception shows that consumers actually focus on valuing a fair price. Price fairness is related to the assessment of consumers whether an outcome and the process of achieving that outcome can be accepted (Bolton et al., in Kaura, 2012). That statement is supported by Xia et al. (2004) in Kaura (2012) that price fairness is the assessment of consumers whether the price set by the seller is acceptable to consumers or logical according to consumers.

\subsection{In store promotion}

Inman, McAlister, \& Hoyer (1990) explained that promotion is any other sign or indicator to attract consumers' attention through various offers so that consumers buy the product. The definition clearly shows that companies or retailers set prices-related strategies through special offers.

Special offers are often designed by retailers for creating positive emotions. Mohan, Sivakumaran, \& Sharma (2013) stated that in store positive feeling (emotion) is related to store atmosphere. One part of creating in store positive feeling is promotion. Sharma, 
Raciti, O'Hara, Reinhard, \& Davies (2013) in their study stated that promotion is effective in increasing sales. Khandai, Agrawal, \& Gulla, (2012) explained that consumers believe that in-store promotion will benefit them. Therefore, in-store promotion has become a retail strategy for increasing sales.

\subsection{Merchandise}

Merchandise is a variety of retail products (Utami, 2010). The diversity of products created from large and or deep strategy. Rohm \& Swaminathan (2004) in Muruganantham \& Bhakat (2013) stated that consumers feel the convenience of shopping at a store that offers complete goods and also the reasonable price, this results in an urge to buy more. Thus, that study emphasizes that the diversity of products and logical prices are the main attraction for consumers to make a purchase. The more diverse products offered by retailers, the greater the impulse buying

\subsection{Time availability}

The internal factors of consumers have a significant influence on shopping. One of them is time availability. Time availability is how much time consumers have when shopping(Huang \& Changhua, n.d.). Referring to this definition, the time availability has an impact on consumers' shopping mood. When consumers have a lot of time when shopping, as a result consumers shop more relaxed. It implies that consumers have time to look at products sold in retail.

Conversely, if consumers are limited in time when shopping, consumers behave hastily when shopping so they don't have a chance to see various products sold in retail. This time limitation can impact negative responses to stimuli provided by retailers, especially stimuli store atmosphere.

\subsection{Impulse buying}

According to Bayley \& Nancarrow (1998) in Park, Kim, \& Forney (2006), impulse buying is a sudden purchase behavior without planning so that consumers tend not to carry out the process of searching and processing information. Therefore, consumers ignore various considerations when making purchases as a result of spontaneous buying behavior. 
Meanwhile, Isen (1984) in Park et al., (2006) described that positive emotions in retail affect purchasing decisions quickly and also reduce the complexity of decision making. Consumers who feel comfortable and have a positive mood during the shopping process will have a higher probability of making impulse buying and vice versa.

Positive mood is formed by two factors, namely external factors and internal factors of consumers. External factors are factors outside consumers and affect emotions, such as sales promotions, prices, store atmosphere and so on. While internal factors are a factor in consumers, namely the mood of consumers when shopping, for example the time availability (Abdolvand et.al., 2011).

\section{Analysis}

\subsection{Population and sample}

The population in this study were the people of Ex Surakarta residency who had shopped on the national mini market chain, namely Alfamart and Indomaret. Referring to members of the population, this study uses a nonprobailty sampling approach with a sampling method using purposive sampling method. The sample which represents the population in this study are members of the population who have made impulse buying.

The sample target was 150 respondents, 120 respondents returned the questionnaire, so the response rate is $80 \%$. However, 15 questionnaires were not filled in completely and 5 questionnaires did not meet the criteria. According to the respondents profile, the majority of respondents in this study were women (67\%), the age range between 16-30 years old (93\%) with education dominated by students (81\%). Based on the characteristics of the respondents, the research respondents have good knowledge of decision making in shopping

\subsection{Intrument testing}

\subsubsection{Validity testing}

Validity testing is done to ensure that the questionnaire's indicators actually measure the variables that should be measured. Table 1 shows that all questionnaire items passed the validity test with loading factor more than 0.6. (Sekaran, 2006), 
TABLE 1: Output of Validity Testing.

\begin{tabular}{|c|c|c|c|c|c|}
\hline & $\begin{array}{l}\text { Price } \\
\text { Fairness }\end{array}$ & $\begin{array}{l}\text { In Store } \\
\text { Promotion }\end{array}$ & Merchandise & $\begin{array}{l}\text { Time } \\
\text { Availability }\end{array}$ & $\begin{array}{l}\text { Impulse } \\
\text { Buying }\end{array}$ \\
\hline $\mathrm{H} 1$ & 0.881 & & & & \\
\hline H3 & 0.61 & & & & \\
\hline H4 & 0.718 & & & & \\
\hline ISP1 & & 0.799 & & & \\
\hline ISP2 & & 0.836 & & & \\
\hline ISP3 & & 0.835 & & & \\
\hline ISP4 & & 0.92 & & & \\
\hline ME1 & & & 0.76 & & \\
\hline ME2 & & & 0.791 & & \\
\hline ME3 & & & 0.882 & & \\
\hline ME4 & & & 0.781 & & \\
\hline ME5 & & & 0.873 & & \\
\hline TA1 & & & & 0.731 & \\
\hline TA2 & & & & 0.873 & \\
\hline TA4 & & & & 0.912 & \\
\hline IB3 & & & & & 0.734 \\
\hline IB5 & & & & & 0.791 \\
\hline IB6 & & & & & 0.882 \\
\hline IB7 & & & & & 0.776 \\
\hline IB8 & & & & & 0.787 \\
\hline
\end{tabular}

\subsubsection{Reliability testing}

Reliability testing is testing the consistency of the research's instruments. A measuring instrument, in this case is the research questionnaire, must have high consistency when used. This Testing is based on the Cronbach Alpha and Average Variance Extracted (AVE) values. Rule of thumb reliability test is the cronbach alpha score $\geq 0.6$ and AVE value $\geq 0.5$ (Sekaran, 1992).

Table 2 is the cronbach alpha scores and AVE values of observational variables in this study. The overall value of cronbach Alpha meets the rule of thumb. So, all variables passed the reliability test.

\subsection{Data analysis and discussion}

\subsubsection{Data analysis}

The analytical method used in this study is Structural Equation Modeling (SEM)) using Partial Least Square (PLS) software. SEM is a Multivariate technique that combines 
TABLE 2: Output of Reliability Testing.

\begin{tabular}{lcc}
\hline & Cronbach Alpha & AVE \\
\hline $\begin{array}{l}\text { Price } \\
\text { Fairness }\end{array}$ & 0.647 & 0.555 \\
$\begin{array}{l}\text { In Store } \\
\text { Promotion }\end{array}$ & 0.872 & \\
$\begin{array}{l}\text { Merchandise } \\
\text { Time }\end{array}$ & 0.876 & 0.633 \\
Availability & & 0.671 \\
$\begin{array}{l}\text { Impulse } \\
\text { Buying }\end{array}$ & 0.805 & \\
\hline
\end{tabular}

aspects of multiple regression and factor analysis to estimate a series of simultaneous dependency relationships (Hair et. al., 1998). Independent variables include Price Fairness, In Store Promotion, and Merchandise. The moderating variable is time availability, while the dependent variable is Impulse Buying (Figure 1).

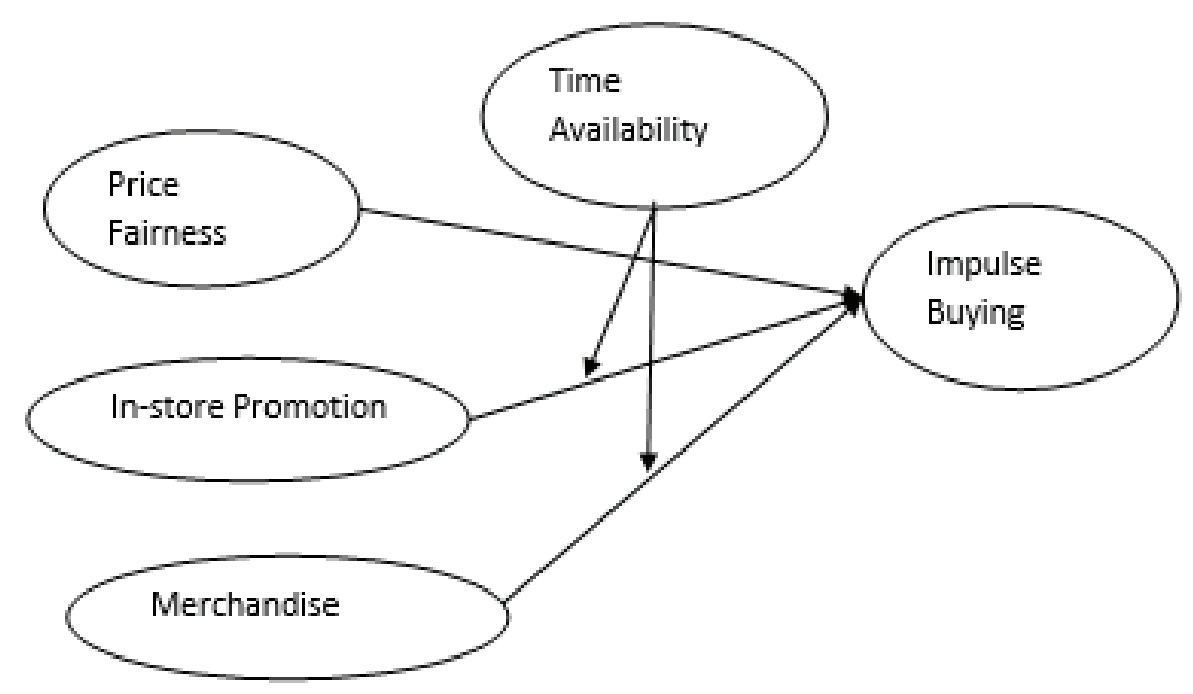

Figure 1: Research Model. 
Global of Goodness of Fit (GoF). In accordance with Tenenhaus, Vinzi, Chatelin, \& Lauro, (2005), measurement of the research model for Partial Least Square can be seen by calculating the GoF value. The GoF value is calculated using the following formula:

$$
\begin{gathered}
G o F=\sqrt{\text { Average Communality } \times \text { Average } R^{2}} \\
G o F=\sqrt{0.658 \times 0.292}=0,4383
\end{gathered}
$$

The GoF value obtained in this study is 0.4383 which exceeds the cut-off value of 0.36 . It means the research model is fit

SEM-PLS. Data analysis using software smartpls 3. The results of SEM-PLS analysis are shown in table 3 . Testing the influence between variables constructed based on the $5 \%$ significance level at $95 \%$ degree of confidence. The $T$ table value at $5 \%$ significance is 1.96, this indicates that the influence between the observed variables is stated to have an influence if the significance value ( $P$ Values) $\leq 0.05$ or T value (T Statistics) $\geq$ 1.96 .

TABLE 3: Output SEM-PLS.

Path Coefficients
\begin{tabular}{|l|r|r|r|r|r|r|}
\hline Mean, STDEV, T-Values, P-Va... & 圆 Confidence Intervals & Confidence Intervals Bias C... & Samples & Copy to Clipboard: & Excel Format \\
\hline & Original Sampl... & Sample Mean (... & Standard Devia... & T Statistics (10... & P Values & \\
\hline Harga -> Impu... & 0.204 & 0.220 & 0.099 & 2.047 & 0.041 \\
\hline InStorePromoti... & 0.280 & 0.279 & 0.110 & 2.537 & 0.011 \\
\hline Merchandise -... & 0.214 & 0.206 & 0.102 & 2.104 & 0.036 \\
\hline Moderating Eff... & 0.006 & 0.011 & 0.122 & 0.052 & 0.959 \\
\hline Moderating Eff... & 0.107 & 0.088 & 0.124 & 0.861 & 0.389 \\
\hline TimeAvailable... & 0.005 & -0.003 & 0.154 & 0.030 & 0.976 \\
\hline
\end{tabular}

Based on the results of SEM-PLS analysis, the variable of Price Fairness, In Store Promotion, and Merchandise affect the Impulse Buying variable with the T Statistics amount of 2,047; 2,537; and 2,104 in sequence. Furthermore, the variable of Time Availability is not a moderating variable affecting between In Store Promotion and the Impulse Buying and also between Merchandise to Impulse Buying. This can be seen in the T Statistics values below 1.96, i.e 0.052 and 0.861 respectively.

\subsubsection{Discussion}

The results of this study indicate that impulse buying behavior is influenced by consumer perceptions of logical prices. The more consumers perceive that the price of the product is reasonable, the stronger the urge to impulse buying. The results of this study are in accordance with the research Kaura (2012); Chen \& Zhang (1982) which states that store 
stimuli have an impact on purchasing impulse. This result is also supported by Wong \& Zhou (2003) in Tinne (2010).

In addition, In Store Promotion also affects the Impulse Buying. Store stimuli especially the internal promotion encourage consumers to make purchasing decisions quickly without planning. Inman et al. (1990) stated that in-store discount strategies trigger consumers to make unplanned purchases, while out store promotions have different effects.

Impulse buying is also influenced by the variety of products offered in stores. The large selection of goods stimulates consumers to behave unplanned in purchasing. According to Tinne (2010) impulse buying are influenced by various variables, one of which is the product characteristics along with the diversity of products in the retail.

This study also shows that the variable of time availability is not a variable that strengthens or weakens the influence between observational variables. This is different from the results of Wiyono, Haryanto \& Hastjarja (2018) research which states that the variable of time availability is a variable that strengthens the influence between the variables of in store promotion on the variable of impulse buying. This difference in results is possible because of different research settings. This research setting is a national mini retail chain, while the study settings of Wiyono et al. (2018) is an international hyper market where the store area is wide and also the corridor space. So, consumers who visit mini retail tend to be in a hurry to immediately finish shopping, because it is not possible for sight-seeing like a hyper market. Based on Tinne (2010), store characteristics and store situation are important elements in impulse buying.

\section{Conclusion}

This study analyzes the influence of the variable of Price Fairness, In Store Promotion and Merchandise on Impulse Buying variable, as well as the moderating effect of Time Availability variable. Overall the results of the study indicate that spontaneous purchases made by retail consumers are influenced by the price fairness offered by retailers. In addition, promotions in stores and merchandise offered by retailers also influence spontaneous buying behavior.

Internal consumer variable, namely Time Availability is not a moderating variable. This study shows that the setting factor must be considered for testing the moderating effect. 


\section{References}

[1] Balaji, K., \& Babu, K. M. (2015). Impulse buying behavior-the literature review. International Journal of Social Science \& Interdisciplinary Research, 4(5), 121-137. Retrieved from http://indianresearchjournals.com/pdf/IJSSIR/2015/May/15.pdf

[2] Chen, T. (2008). Online Impulse Buying and Product Involvement. Communications of the IBIMA, 5, 74-81. Retrieved from http://www.mendeley.com/research/onlineimpulse-buying-product-involvement/

[3] Chen, Y., \& Zhang, L. (1982). Influential Factors for Online Impulse Buying in China?: a Model and Its Empirical Analysis, 45-51.

[4] Huang, L., \& Changhua, N. (n.d.). What Drives Consumer Impulse Buying?? Evidence from a Retail Setting in Taiwan.

[5] Inman, J. J., McAlister, L., \& Hoyer, W. D. (1990). Promotion Signal: Proxy for a Price Cut? Journal of Consumer Research, 17, 74-81.

[6] Kaura, V. (2012). A Link for Perceived Price, Price Fairness and Customer Satisfaction. Pacific Business Review International, 5(6).

[7] Khandai, S., Agrawal, B., \& Gulla, A. (2012). Visual Merchandising As An Antecedent To Impulse Buying?: An Indian Perspective. International Journal of Business and Management Studies, 1(1), 267-277.

[8] Mohan, G., Sivakumaran, B., \& Sharma, P. (2013). Impact of store environment on impulse buying behavior. European Journal of AMrketing, 47(10), 1711-1732. https: //doi.org/10.1108/EJM-03-2011-0110

[9] Park, E. J., Kim, E. Y., \& Forney, J. C. (2006). A Structural Model of Fashion-Oriented Impulse Buying Behavior. Journal of Fashion Marketing and Management, 10(4), 433-446. https://doi.org/10.1108/13612020610701965

[10] Sekaran, U. (1992). Research Methods for Business: A Skill Building Approach (Second Edi). Singapore: John Willey \& Sons, Inc.

[11] Sekaran, U. (2006). Reseach Method of Business. (S. Empat, Ed.) (4th ed.). Jakarta.

[12] Tenenhaus, M., Vinzi, V. E., Chatelin, Y. M., \& Lauro, C. (2005). PLS path modeling. Computational Statistics and Data Analysis, 48(1), 159-205. https://doi.org/10.1016/ j.csda.2004.03.005

[13] Tinne, W. S. (2010). Impulse Purchasing?: A Literature Overview. ASA University Review, 4(2), 65-73.

[14] Zeithaml, V. A. (1988). Consumer Perceptions of Price, Quality, and Value: A MeansEnd Model and Snthesis of Evidence. Journal of Marketing, 52, 2-22. 